\title{
Regionalisation of Intensity-Frequency-Duration Data: A Case Study for New South Wales
}

\author{
W.L. Caballero, M. Taylor, A. Rahman and S. Shrestha \\ School of Engineering, University of Western Sydney, New South Wales \\ Email:Mel.Taylor@uws.edu.au
}

\begin{abstract}
Design flood estimation is often required in hydrological design, floodplain management and soil conservation studies. Australian Rainfall and Runoff (ARR), the national guide for flow estimation in Australia, currently recommends the Design Event Approach (DEA), which is a rainfall-based flood estimation method. The method considers the probabilistic nature of rainfall intensity in combination with other model input parameters, such as rainfall temporal patterns and initial loss. The key assumption involved in the DEA is that the representative design input and parameters in modelling can be defined in such a way that they are "annual exceedance probability (AEP) neutral", i.e. it produces a flood peak output that has the same AEP as the rainfall input. However, this assumption is generally not satisfied and the arbitrary treatment of various flood producing variables can lead to inconsistencies and significant bias in flood estimates for a given AEP.

In recent years, there has been considerable research on the development and application of the Joint Probability Approach/Monte Carlo Simulation Technique (MCST) to design flood estimation. The previous applications of this method with Victoria and Queensland data have shown that MCST can overcome some of the limitations associated with the DEA, and this can produce more accurate design flood estimates. The wider application of the MCST needs regionalisation of various input variables to the rainfall-runoff model. These input variables include various rainfall parameters, such as duration, intensity, temporal pattern and losses. Of these, rainfall intensity, i.e. Intensity-Frequency-Duration (IFD) data, is the most important one. This paper focuses on the regionalisation of the IFD data for New South Wales (NSW) so that this can be used with the MCST to obtain design flood estimates.
\end{abstract}

This study uses 83 pluviograph stations across NSW to regionalise the IFD data. In the application, complete storm rainfall events are selected from each of the 83 pluviograph stations in NSW. An exponential distribution is fitted to the selected partial duration series data for each station to obtain rainfall quantile estimates. A polynomial is then fitted to obtain rainfall quantile estimates for any duration and Average Recurrence Interval (ARI). These are then used to construct an IFD table for each station. The IFD tables from the selected 83 pluviograph stations form the basis of regionalisation of the IFD data in NSW as discussed in this paper.

An 'Inverse Distance Weighting (IDW) method' is adopted to obtain IFD estimates for a location of interest (where regional IFD estimation is needed) from the nearby pluviograph stations. The IDW method assigns weight to pluviograph stations as a function of distance from the location of interest in such a way that the weight is inversely proportional to distance. It has been found that three to five nearby stations (depending on the spatial density of the available pluviograph stations) can be used to obtain reasonably accurate regional IFD estimates for NSW. The new IFD data is applied with the Design Event Approach to two NSW catchments for estimating design floods. The application of the MCST to these study catchments is yet to be undertaken which will require derivation of the stochastic rainfall duration, temporal patterns and losses, which is currently being undertaken.

Keywords: Complete storm, Monte Carlo simulation, Design rainfall, Joint Probability Approach, Design Event Approach, Australian Rainfall and Runoff 


\section{INTRODUCTION}

Design flood estimation is often required in hydrological design of water resource projects, flood plain management and soil conservation studies. Australian Rainfall and Runoff (ARR 1987), the national guide for flow estimation in Australia, currently recommends the Design Event Approach (DEA) as the preferred method of rainfall runoff modelling (I. E. Aust., 1987). This method considers the probabilistic nature of rainfall intensity in combination with other model input parameters, such as rainfall temporal patterns and initial loss that are kept constant. The key assumption involved in DEA is that the representative design input and parameters in modelling can be defined in such a way that they are "annual exceedance probability (AEP) neutral", i.e. it produces a flood peak output that has the same AEP as the rainfall intensity. However, this assumption is generally not satisfied (Hill and Mein 1996) and the arbitrary treatment of various flood producing variables can lead to inconsistencies and significant bias in flood estimates for a given AEP. This might lead to the under-estimation or over-estimation of flow resulting in inadequate water infrastructure projects, both with considerable financial cost.

The earlier studies of Eagleson (1972), Beran (1973), Russell et al. (1979), Diaz-Granados et al. (1984) and Sivapalan et al. (1990) on the Joint Probability Approach (JPA) to flood estimation were reviewed by Rahman et al. (1998). They found that the majority of the earlier applications were limited to theoretical studies. Mathematical complexity, difficulties in parameter estimation and limited flexibility usually prevented the application of these methods under practical situations. Rahman et al. (2002) developed and applied successfully a simplified Monte Carlo Simulation Technique (MCST) for flood estimation based on the principles of joint probability that can employ most of the commonly adopted flood estimation models and design data in Australia. This method has the potential to provide more accurate design flood estimates than the existing DEA. In addition, this method has enough flexibility to be adopted in practical situations; however, the new MCST has not been investigated under different hydrologic conditions. Further improvement such as the derivation of design data is needed for its routine application.

In recent years, there has been considerable research (such as Heneker et al., 2002; Kuczera et al., 2003; Aronica and Candela, 2004, 2007) on the development and application of the JPA/MCST in design flood estimation. Aronica and Candela (2007) adopted a semi-distributed stochastic rainfall-runoff model suited for ungauged or partially gauged catchments. They found that the method can reproduce the observed flood frequency curves with reasonable accuracy over a wide range of return periods using a simple and parsimonious hydrologic model, limited data input and without any calibration of the adopted hydrologic model. The method used the Soil Conservation Service-Curve Number (SCS-CN) method adopted by USDA Soil Conservation Service (1986) to transform storm depth to effective rainfall depth and used the Generalised Likelihood Uncertainty Estimation to estimate the uncertainty associated with the antecedent soil moisture affecting the derivation of flood frequency curve. The SCS-CN method is rarely adopted in Australia; instead non-linear runoff routing models are preferred.

The MCST by Rahman et al. (2002) uses a non-linear runoff routing model to simulate streamflow hydrographs. The previous applications of this method, such as the MCST by Carroll and Rahman (2004) with Victoria and Queensland data have shown that this method can overcome some of the limitations associated with the DEA, and this can produce more accurate design flood estimates. However, the wider application of the MCST needs regionalisation of various input parameters to the rainfall-runoff model. These input variables include various rainfall parameters, such as duration, intensity, temporal pattern and losses. Of these, rainfall intensity, i.e. Intensity-Frequency-Duration (IFD) data, is the most important. This paper focuses on the regionalisation of the IFD data for New South Wales (NSW) so that this can be used with the DEA and MCST to obtain design flood estimates.

\section{STUDY AREA AND DATA}

This study uses three types of data (pluviograph, daily rainfall, and streamflow data) from the state of NSW. The continuous rainfall data from 83 pluviograph stations in NSW were obtained from Australian Bureau of Meteorology. The rainfall record lengths of the selected stations range from 31 years to 97 years with an average record length of 44 years. The selected stations present a good spatial distribution over the eastern part of the state (as shown in Figure 1). However, due to lack of quality data, no station is selected from far western NSW. Two catchments have been selected (Table 1) to test the new regionalised IFD data. A total of 6 daily rainfall stations are selected in the study (Table 2) for derivation of the catchment average rainfall in estimating design losses. The daily rainfall stations selected have a minimum threshold record length of 20 years. 


\section{METHODS}

\subsection{Selection of storm events}

To apply JPA/MCST, one needs to define storm events which can produce rainfall events with duration as a random variable unlike ARR 87, which adopts a predefined duration. Hoang et al. (1999) and Rahman et al. (2002) defined a rainfall event of random durations as a 'complete storm' (CS) and 'storm-core'. The complete storm is defined as a period of significant rain preceded and followed by an arbitrarily defined period of dry hours (e.g. 6 hours, as adopted in this study). A storm-core is defined as the most intense part of a complete storm.

The complete storms from the selected 83 pluviograph stations are selected based on

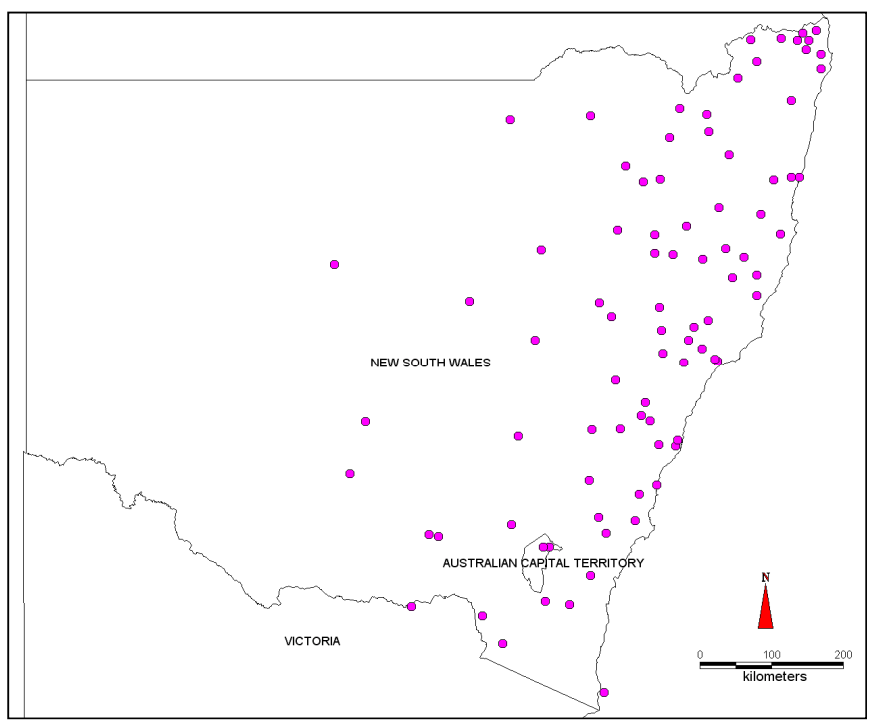

Figure 1. Selected 83 Pluviograph Stations in NSW an arbitrary threshold value of rainfall intensity in such a way that 2 to 8 rainfall events on average are selected per year. The selected complete storms are Table 1. Selected Catchments in NSW for Rainfall Runoff Modelling

\begin{tabular}{|c|c|c|c|c|}
\hline Station ID & Station Name & Area $\left(\mathrm{km}^{2}\right)$ & Period of Record & $\begin{array}{c}\text { Record Length } \\
\text { (y ears) }\end{array}$ \\
\hline 201001 & Oxley River @ Eungella & 213 & $1958-2006$ & 49 \\
\hline 204025 & Orara River @ Karangi & 135 & $1970-2006$ & 37 \\
\hline
\end{tabular}
then analysed to develop the IFD curves. The previous study by Rahman et al. (2002) focused on storm-cores; however, this study focuses on complete storms. It is believed that complete storms are easy to identify and the rainfall temporal patterns and losses can be analysed easily for a complete storm as compared to a storm-core. A complete storm-based MCST is therefore likely to provide a more comprehensive design flood estimation method.

Table 2. Selected Daily Rainfall Stations for Catchments 201001 and 204025

\begin{tabular}{|c|c|c|c|c|c|}
\hline $\begin{array}{l}\text { Catchment } \\
\text { Station ID }\end{array}$ & $\begin{array}{c}\text { Daily Rainfall } \\
\text { Station ID } \\
\end{array}$ & Daily Rainfall Station Name & $\begin{array}{c}\text { Distance from } \\
\text { centre }(\mathrm{km}) \\
\end{array}$ & Period of Record & $\begin{array}{c}\text { Record Length } \\
\text { (years) }\end{array}$ \\
\hline \multirow{3}{*}{201001} & 58057 & Tyalgum (Wanungara View) & 4.25 & $1950-2009$ & 60 \\
\hline & 58005 & Brays Creek (Misty Mountain) & 4.60 & $1950-2010$ & 61 \\
\hline & 58036 & Chillingham (Limpinwood) & 6.41 & $1928-2010$ & 83 \\
\hline \multirow{3}{*}{204025} & 59095 & Upper Orara (Dairy ville) & 1.23 & $1970-2010$ & 41 \\
\hline & 59101 & Upper Orara (Fairview) & 4.06 & $1971-1993$ & 23 \\
\hline & 59078 & Promised Land Bellingen (Cry stal Creek) & 9.52 & $1966-2010$ & 45 \\
\hline
\end{tabular}

\subsection{Development of regional IFD data}

From each of the 83 pluviograph stations, the complete storm event (partial series) data is extracted. An exponential distribution is fitted to these partial series rainfall intensity data, $I_{i}(i=1, \ldots, M)$, where $M$ is the number of data points in the series for a given duration $\left(D_{c s}\right)$. The rainfall quantiles (for a given duration) are obtained from the following equation:

$I(T)=I_{0}+\beta \ln (\lambda T)$

where $I_{0}$ is the smallest value in the series; $\beta=\sum I_{i} / M-I_{0} ; \lambda=M / N ; N$ is the number of years of data; and $T$ is the ARI in years. Equation (1) is applied to a number of durations. A second degree polynomial is then fitted (for a given ARI) to obtain rainfall quantile estimates for any duration:

$\log \left(I_{c s}\right)=a\left(\log \left(D_{c s}\right)\right)^{2}+b\left(\log \left(D_{c s}\right)\right)+c$

where $I_{c s}$ is the rainfall intensity for complete storm, $a, b$ and $c$ are regression coefficients estimated from the observed data. Equations (1) and (2) are used to construct an IFD table for each station.

The IFD tables from the selected 83 pluviograph stations form the basis of regionalisation of the IFD data in NSW. An 'Inverse Distance Weighting (IDW) method' is proposed to obtain IFD estimate for an arbitrary 
location from the IFD data of the nearby stations. The IDW method assigns weight to pluviograph stations as an inverse function of distance from the point of interest (where regional IFD estimate is needed) (Figure 2). The weights are estimated as below:

$$
\begin{aligned}
& w_{1}=\left(x_{2} x_{3} \ldots x_{n}\right) /\left[\left(x_{2} x_{3} \ldots x_{n}\right)+\left(x_{1} x_{3} \ldots x_{n}\right)+\left(x_{1} x_{2} \ldots x_{n}\right)+\left(x_{1} x_{2} x_{3} \ldots x_{n-1}\right)\right] \\
& w_{2}=\left(x_{1} x_{3} \ldots x_{n}\right) /\left[\left(x_{2} x_{3} \ldots x_{n}\right)+\left(x_{1} x_{3} \ldots x_{n}\right)+\left(x_{1} x_{2} \ldots x_{n}\right)+\left(x_{1} x_{2} x_{3} \ldots x_{n-1}\right)\right] \\
& w_{3}=\left(x_{1} x_{2} \ldots x_{n}\right) /\left[\left(x_{2} x_{3} \ldots x_{n}\right)+\left(x_{1} x_{3} \ldots x_{n}\right)+\left(x_{1} x_{2} \ldots x_{n}\right)+\left(x_{1} x_{2} x_{3} \ldots x_{n-1}\right)\right] \\
& w_{n}=\left(x_{1} x_{2} x_{3} \ldots x_{n-1}\right) /\left[\left(x_{2} x_{3} \ldots x_{n}\right)+\left(x_{1} x_{3} \ldots x_{n}\right)+\left(x_{1} x_{2} \ldots x_{n}\right)+\left(x_{1} x_{2} x_{3} \ldots x_{n-1}\right)\right]
\end{aligned}
$$

where $w_{1}, w_{2}, w_{3}, \ldots, w_{n}$ are the weights, $x_{1}, x_{2}, x_{3}, \ldots, x_{n}$ are the distances from the point of interest and $n$ is the number of stations selected for the averaging. The weighted average rainfall intensity $\left(I_{w}\right)$ at the location of interest can be obtained from:

$I_{w}=w_{1} I_{1}+w_{2} I_{2}+\ldots+w_{n} I_{n}$

where $I_{1}, I_{2}, \ldots, I_{n}$ are design rainfall intensity (IFD value) at station $1,2, \ldots, n$ respectively. It is assumed that stations located beyond $30 \mathrm{~km}$ distance from the point of interest should not be included in obtaining $I_{w}$.

\subsection{Rainfall runoff modelling}

Two catchments are selected to apply the developed IFD curves in rainfall runoff modelling. Three daily rainfall stations located within $5 \mathrm{~km}$ of the catchment boundary are also selected for each catchment to obtain catchment average rainfall in estimating losses. The daily

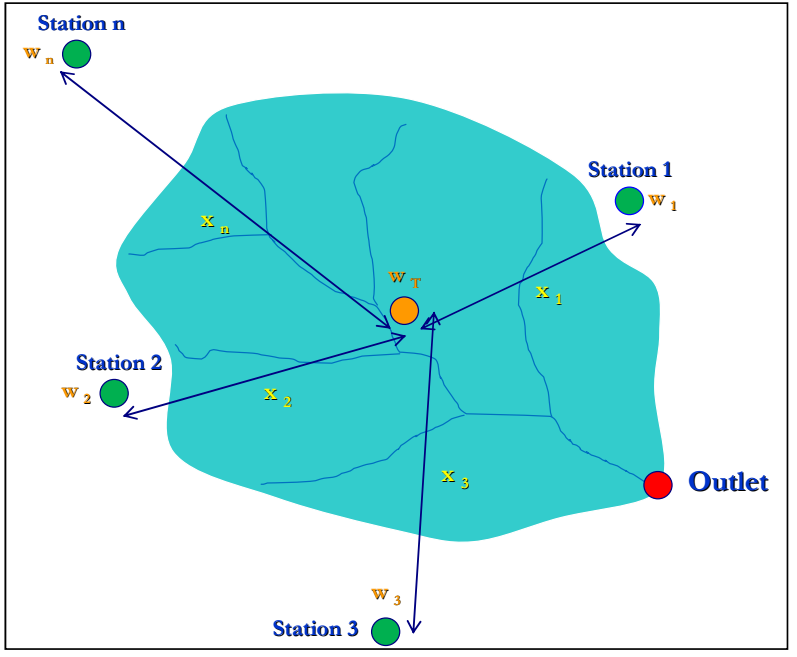

Figure 2. Illustration of catchment weighting scheme rainfall data are disaggregated to hourly data using the temporal patterns of the pluviograph data located within/near the catchment. The disaggregated data plus the pluviograph data within the catchment are then used for obtaining the catchment average rainfall. Significant rainfall and runoff events are selected for each study catchment for the calibration of the following runoff routing model:

$S=k Q^{m}$

where $S$ is the storage $\left(\mathrm{m}^{3}\right), k$ is the storage delay parameter $(\mathrm{h}), Q$ is the discharge $\left(\mathrm{m}^{3} / \mathrm{s}\right)$ and $m$ is the nonlinearity parameter, which is taken as 0.8 in this application.

The baseflow separation is achieved by using the following equation (Boughton (1988):

$B F_{i}=B F_{i-1}+\alpha\left(S F_{i}-B F_{i-1}\right)$

where $B F_{i}$ is the rate of baseflow at any time step $i\left(\mathrm{~m}^{3} / \mathrm{s}\right), B F_{i-1}$ is the rate of baseflow in the previous time step $\left(\mathrm{m}^{3} / \mathrm{s}\right), \alpha$ is the fraction of surface runoff and $S F_{i}$ is the total streamflow at step $i$.

At the initial condition, the baseflow is assumed to be equal to the streamflow $\left(B F_{1}=S F_{l}\right)$ at the beginning of surface runoff. To apply (9) for a given catchment, the parameter value $\alpha$ needs to be estimated from the observed streamflow events and the design $\alpha$ value should be selected in such a way that this provides an acceptable baseflow separation for all the selected events in the catchment.

The continuing loss is estimated from the following equation:

$R=I L+C L * t_{1}+Q F$

where $R$ is the total rainfall of the event expressed in average depth of rainfall $(\mathrm{mm})$ over the catchment. The initial loss $(I L)$ is defined as the amount of rainfall that occurs before the start of the runoff in mm, while continuing loss $(C L)$ is the average rate of loss in $\mathrm{mm} / \mathrm{h}$ throughout the remainder of the rainfall event. The $t_{l}$ is the time elapsed between the start of the surface runoff and end of the rainfall event $(\mathrm{h})$. The $Q F$ is the quickflow, expressed in $\mathrm{mm}$, assumed to result from the rainfall event. Since, $Q F$ is the total streamflow $\left(S F_{T}\right)$, expressed in mm, minus $B F,(10)$ may be written as: 
$R=I L+C L * t_{1}+S F_{T}-B F$

From (10) $C L$ may be expressed as:

$C L=(R-I L-Q F) / t_{1}$

To estimate QF in (12), separation of baseflow from total streamflow is required, as previously discussed in this section.

\subsection{Model evaluation}

The estimated flood quantiles $\left(Q_{\text {pred }}\right)$ from the rainfall-runoff modelling (based on the regional IFD data) are compared against the at-site flood frequency analysis estimates $\left(Q_{\mathrm{FFA}}\right)$ obtained by fitting the Bayesian-Log-Pearson Type 3 distribution using FLIKE software (Kuczera, 1999)

to the at-site annual maximum flood series data. In this regard, a relative error (RE) is defined as below:

$$
R E(\%)=\left[\left(Q_{\text {pred }}-Q_{F F A}\right) / Q_{F F A}\right] \times 100
$$

\section{RESULTS}

A total of 18,856 complete storm events from the 83 pluviograph stations are selected. On average, 227 complete storm events are selected from a pluviograph station ( 5 events per year on average). An IFD table is derived for each of the 83 pluviograph stations (sample shown in Figure 3). The derived IFD tables look consistent with no kinks in the curves and rainfall intensity decreases with increasing duration as expected (as can be seen in Figure 3). These IFD tables can be used to obtain a value of rainfall intensity $I_{c s}$ for any duration $D_{c s}$ for a selected ARI.

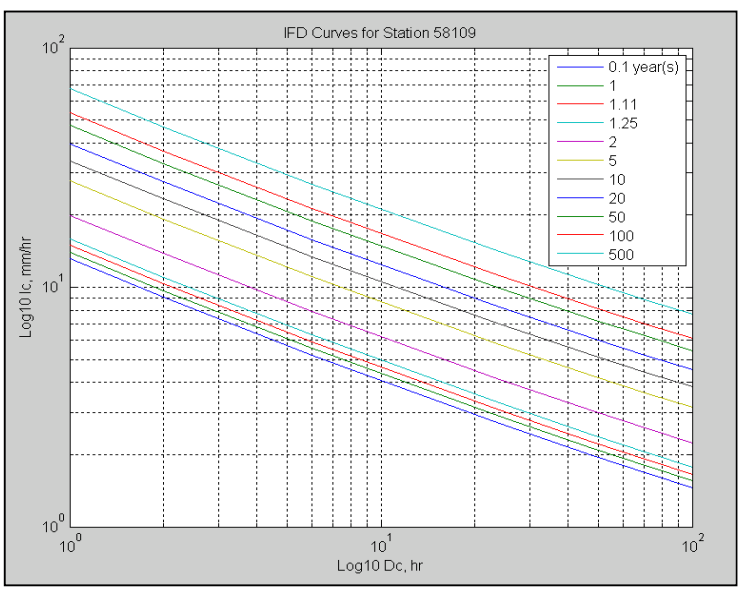

Figure 3. IFD Curves for Station 58109

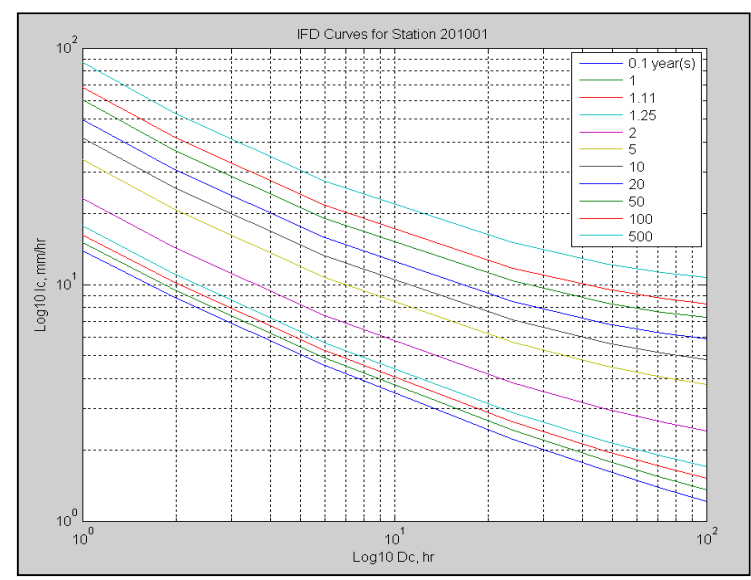

Figure 4. Weighted Average IFD Curves for Catchment 201001

The IFD data for catchment 201001 is obtained using IDW method (Section 3.2) based on at-site IFD table from nearby pluviograph stations 58109 (located within the catchment), 58129, 58113, 58158 and 58044, with distances $2.14 \mathrm{~km}, 13.92 \mathrm{~km}, 16.24 \mathrm{~km}, 18.95 \mathrm{~km}$ and $26.64 \mathrm{~km}$, respectively from the centre of catchment 201001. The resulting IFD curves for catchment 201001 (Figure 4) look very similar to the IFD curves of the nearby stations (Figure 3). Similarly, IFD curves for catchment 204025 is obtained using at-site IFD curves from nearby pluviograph stations 59026 (located within the catchment), 59040 and 59067, with distances $3.20 \mathrm{~km}, 14.81 \mathrm{~km}$ and $25.38 \mathrm{~km}$, respectively. In this case, only three pluviograph stations are used as other stations are located beyond the adopted $30 \mathrm{~km}$ limit. The resulting IFD curves were found to be very similar to the IFD curves of the nearby stations, indicating no gross error with the method.

A total of 5 rainfall runoff events were selected for each of the catchments 201001 and 204025 for estimating IL, CL and runoff routing model parameter $k$. The runoff routing model calibration data for these catchments are tabulated in Tables 3 and 4, respectively.

In this paper, DEA is adopted in estimating the flood quantiles for the selected catchments. Here a number of trial rainfall durations are adopted for each ARI of interest following the principles of DEA. The corresponding IFD data is obtained from
Table 3. Model Calibration Summary for Catchment 201001

\begin{tabular}{|c|c|c|c|c|c|c|c|c|c|}
\hline Event & Start Date & End Date & Total Rainfall & $\mathrm{Q}_{\text {obs }}$ & $\mathrm{Q}_{\text {pred }}$ & $\alpha$ & $\mathrm{IL}(\mathrm{mm})$ & $\mathrm{CL}(\mathrm{mm} / \mathrm{h})$ & $\mathrm{k}(\mathrm{h})$ \\
\hline 1 & $20 / 02 / 1977$ & $22 / 02 / 1977$ & 111.5 & 42 & 40 & 0.003 & 66.1 & 1.64 & 47.65 \\
\hline 2 & $16 / 03 / 1978$ & $19 / 03 / 1978$ & 361.1 & 716 & 703 & 0.001 & 24.0 & 3.17 & 12.88 \\
\hline 3 & $21 / 01 / 1979$ & $23 / 01 / 1979$ & 132.1 & 141 & 130 & 0.006 & 63.0 & 1.73 & 45.07 \\
\hline 4 & $05 / 02 / 1979$ & $06 / 02 / 1979$ & 71.3 & 98 & 93 & 0.008 & 42.1 & 0.35 & 20.96 \\
\hline 5 & $18 / 06 / 1979$ & $21 / 06 / 1979$ & 190.4 & 278 & 274 & 0.004 & 83.7 & 8.40 & 20.50 \\
\hline \multicolumn{3}{|c|}{ Median } \\
\hline \multicolumn{3}{|c|}{ Average } & & 0.004 & 63.0 & 1.73 & 20.96 \\
\hline \multicolumn{3}{|c|}{} & & 0.0044 & 55.78 & 3.06 & 29.41 \\
\hline
\end{tabular}


ARR1987 and the weighted average IFD table (as described above, e.g. Figure 4). The temporal pattern data is obtained from ARR Volume 2. Different IL-CL values are adopted: median values from calibration (Tables 3 and 4) and ARR1987 design values for NSW (IL $=35 \mathrm{~mm}$ and CL $=2.5 \mathrm{~mm} / \mathrm{h}$ ). The median $k$ values, obtained from model calibration (Tables 3 and 4) are adopted in modelling. For a given ARI, the duration giving the highest flood discharge is taken as the critical duration and the corresponding peak discharge is taken as the design flood for the ARI following DEA.

The critical durations

Table 4. Model Calibration Summary for Catchment 204025

obtained in this study

(Tables 5 and 6) are compared with the time of concentration $\left(t_{c}\right)$ values estimated based on ARR1987 recommended equation $\left(t_{c}=0.76 A^{0.38}\right)$. The critical duration for catchment 201001 (A =

\begin{tabular}{|c|c|c|c|c|c|c|c|c|c|}
\hline Event & Start Date & End Date & Total Rainfall & $\mathrm{Q}_{\text {obs }}$ & $\mathrm{Q}_{\text {pred }}$ & $\alpha$ & $\mathrm{IL}(\mathrm{mm})$ & $\mathrm{CL}(\mathrm{mm} / \mathrm{h})$ & $\mathrm{k}(\mathrm{h})$ \\
\hline 1 & $15 / 02 / 1971$ & $23 / 02 / 1971$ & 192.0 & 72 & 68 & 0.003 & 80.5 & 1.09 & 23.97 \\
\hline 2 & $01 / 03 / 1975$ & $05 / 03 / 1975$ & 197.3 & 80 & 75 & 0.003 & 108.7 & 1.02 & 24.15 \\
\hline 3 & $10 / 02 / 1976$ & $15 / 02 / 1976$ & 233.4 & 140 & 130 & 0.003 & 63.0 & 1.73 & 45.07 \\
\hline 4 & $25 / 12 / 1978$ & $02 / 01 / 1979$ & 196.7 & 77 & 75 & 0.002 & 43.5 & 15.39 & 47.14 \\
\hline 5 & $21 / 01 / 1979$ & $27 / 01 / 1979$ & 234.8 & 117 & 111 & 0.002 & 85.9 & 1.44 & 28.72 \\
\hline \multicolumn{3}{|c|}{ Median } & & 0.003 & 80.5 & 1.44 & 28.72 \\
\hline \multicolumn{3}{|c|}{ Average } & & 0.0026 & 76.32 & 4.13 & 33.81 \\
\hline
\end{tabular}
$213 \mathrm{~km}^{2}$ ) is found to be 12 and 48 hours (Table 5), which is much higher than the ARR1987 estimate of 5.82 hours. Similarly, the critical duration for catchment $204025\left(\mathrm{~A}=135 \mathrm{~km}^{2}\right)$ is 48 hours (Table 6) which is much higher than the ARR1987 estimate of 4.9 hours.

The resulting design floods are summarised in Tables 5 and 6, for catchments 201001 and 204025, respectively. The results are quite mixed, with one catchment showing gross underestimation for all the three cases considered (Table 5) and the other catchment showing overestimation for the two cases and underestimation for one case (Table 6). These results highlight the sensitivity of the final design flood estimates to the selection of the input variables to the model. The application of the MCST to these study catchments is yet to be undertaken which will require derivation of the stochastic rainfall duration, temporal patterns and losses, which is currently being undertaken. The application of MCST is expected to provide a greater insight on various aspects of the derivation of design flood estimates for these catchments, in particular, the probabilistic nature of various input variables and their impacts on design flood estimates.

Table 5. Summary of peak flow estimates for Catchment 201001

\begin{tabular}{|c|c|c|c|c|c|c|c|c|}
\hline \multirow[b]{2}{*}{ Peakflows } & \multicolumn{4}{|c|}{$\mathrm{Q}\left(\mathrm{m}^{3} / \mathrm{s}\right)$} & \multicolumn{3}{|c|}{$\%$ difference } & \multirow[b]{2}{*}{$\begin{array}{c}\text { Critical } \\
\text { Duration } \\
\text { (h) }\end{array}$} \\
\hline & $\begin{array}{c}\text { IL and } \\
\text { CL_calibration } \\
\text { IFD_ARR } 87\end{array}$ & $\begin{array}{c}\text { IL and } \\
\text { CL_ARR_87 } \\
\text { IFD_ARR } 87\end{array}$ & $\begin{array}{c}\text { IL and } \\
\text { CL_calibration }_{\text {_chD I }} \\
\text { IFD }_{w}\end{array}$ & $\begin{array}{c}\text { FFA } \\
\text { Estimation }\end{array}$ & $\begin{array}{c}\text { IL and } \\
\text { CL_calibration } \\
\text { IFD_ARR } 87\end{array}$ & $\begin{array}{c}\text { IL and } \\
\text { CL_ARR_87 } \\
\text { IFD_ARR } 87\end{array}$ & $\begin{array}{c}\mathrm{IL} \text { and } \\
\text { CL_calibration }_{\text {_fib I }} \\
\text { IFD }_{\mathrm{w}}\end{array}$ & \\
\hline$\overline{\mathrm{Q} 2}$ & 345.89 & 389.16 & 191.33 & 353.68 & -2 & 10 & -46 & 48 \\
\hline Q5 & 529.86 & 619.34 & 321.71 & 796.98 & -34 & -22 & -60 & 12 \\
\hline Q10 & 671.80 & 760.70 & 421.73 & 1145.71 & -41 & -34 & -63 & 12 \\
\hline Q20 & 861.84 & 946.78 & 524.34 & 1500.25 & -43 & -37 & -65 & 12 \\
\hline $\bar{Q}$ Q50 & 1104.17 & 1181.43 & 633.43 & 1970.04 & -44 & -40 & -68 & 12 \\
\hline Q100 & 1307.75 & 1380.98 & 733.45 & 2321.62 & -44 & -41 & -68 & 12 \\
\hline
\end{tabular}

Table 6. Summary of peak flow estimates for Catchment 204025

\begin{tabular}{|c|c|c|c|c|c|c|c|c|}
\hline \multirow[b]{2}{*}{ Peakflows } & \multicolumn{4}{|c|}{$\mathrm{Q}\left(\mathrm{m}^{3} / \mathrm{s}\right)$} & \multicolumn{3}{|c|}{$\%$ difference } & \multirow[b]{2}{*}{$\begin{array}{l}\text { Critical } \\
\text { Duration } \\
\text { (h) }\end{array}$} \\
\hline & \begin{tabular}{|c|} 
IL and \\
CL_calibration \\
IFD_ARR 87 \\
\end{tabular} & $\begin{array}{c}\text { IL and } \\
\text { CL_ARR_87 } \\
\text { IFD_ARR } 87\end{array}$ & $\begin{array}{c}\text { IL and } \\
\text { CL_calibration } \\
\text { IFD_I } I_{w}\end{array}$ & $\begin{array}{c}\text { FFA } \\
\text { Estimation }\end{array}$ & $\begin{array}{c}\text { IL and } \\
\text { CL_calibration } \\
\text { IFD_ARR } 87\end{array}$ & $\begin{array}{c}\text { IL and } \\
\text { CL_ARR_87 } \\
\text { IFD_ARR } 87\end{array}$ & $\begin{array}{c}\text { IL and } \\
\text { CL_calibration } \\
\text { IFD_I I }_{\text {w }}\end{array}$ & \\
\hline Q2 & 322.70 & 364.74 & 118.00 & 198.80 & 62 & 83 & -41 & 48 \\
\hline Q5 & 565.60 & 585.78 & 299.35 & 392.74 & 44 & 49 & -24 & 48 \\
\hline Q10 & 724.81 & 736.51 & 432.02 & 550.26 & 32 & 34 & -21 & 48 \\
\hline Q20 & 928.36 & 929.56 & 565.60 & 720.13 & 29 & 29 & -21 & 48 \\
\hline Q50 & 1147.75 & 1137.93 & 711.29 & 964.99 & 19 & 18 & -26 & 48 \\
\hline Q100 & 1355.06 & 1340.97 & 838.65 & 1166.04 & 16 & 15 & -28 & 48 \\
\hline
\end{tabular}

\section{CONCLUSIONS}

This paper investigates the regionalisation of design rainfall intensities (IFD data) for NSW. Based on complete storm events, IFD data at 83 pluviograph stations from NSW are derived. An inverse distance weighting method is proposed to obtain IFD data at any arbitrary location in NSW based on the IFD data of the nearby pluviograph stations. Three to five nearby pluviograph stations (within $30 \mathrm{~km}$ distance) can be 
used to obtain reasonable regional IFD estimates at any arbitrary location in NSW provided there is sufficient number of nearby pluviograph stations. The new IFD data is applied with the Design Event Approach to two NSW catchments for estimating design floods. The application of the MCST to these study catchments is yet to be undertaken which will require derivation of the stochastic rainfall duration, temporal patterns and losses, which is currently being undertaken.

\section{ACKNOWLEDGMENTS}

The authors would like to acknowledge the Bureau of Meteorology for providing the pluviograph data for NSW, the NSW Office of Water for streamflow data and Mr. Khaled Haddad for his guidance.

\section{REFERENCES}

Aronica, G.T. and Candela, A. (2004). A regional methodology for deriving flood frequency curves (FFC) in partially gauged catchments with uncertain knowledge of soil moisture conditions. The International Environmental Modelling and Software Society Conference, Complexity and Integrated Resources Management, Osnabruck, Germany, June 14-17, 2004, 1147-1152.

Aronica, G.T. and Candela, A. (2007). Derivation of flood frequency curves in poorly gauged Mediterranean catchments using a simple stochastic hydrological rainfall-runoff model. Journal of Hydrology, 347 (1-2), 132-142.

Beran, M.A. (1973). Estimation of design floods and the problem of equating the probability of rainfall and runoff. Proceedings of the Madrid Symposium: Design of Water Resources Projects with Inadequate Data, Madrid, Spain, June 1973, 459-471.

Boughton, W. C. 1988. Partitioning streamflow by computer. The Institution of Engineers, Australia, Civil Engineering Transactions, 285-291.

Carroll, D.G. and Rahman, A. (2004). Investigation of sub-tropical rainfall characteristics for use in the Joint Probability Approach to design flood estimation. In Proceedings of Second Asia Pacific Association of Hydrology and Water Resources (APHW) Conference, Singapore, July 5-8, 2004, 8 pp.

Diaz-Granados, M.A., Valdes, J.B. and Bras, R.L. (1984). A physically based flood frequency distribution. Water Resources Research, 20 (7), 995-1002.

Eagleson, P.S. (1972). Dynamics of flood frequency. Water Resources Research, 8 (4), 878-898.

Heneker, T.M., Lambert, M.F. and Kuczera, G. (2002). Overcoming the joint probability problem associated with initial loss estimation in design flood estimation. Proc. $27^{\text {th }}$ National Hydrology and Water Resources Symposium, The Water Challenge, Balancing the Risk, Institution of Engineers Australia, Melbourne, Australia, May 20-23, 2002, CD-ROM Publication, ISBN 085825778 5, 9 pp.

Hill, P. I. and Mein, R. G. (1996). Incompatibilities between storm temporal patters and losses for design flood estimation. Hydrology and Water Resources Symposium 1996, Hobart, Tasmania, 2, 445-451.

Hoang, T. M. T., Rahman, A., Weinmann, P. E., Laurenson, E. M., and Nathan, R. J. (1999). Joint probability descriptions of design rainfalls. International Hydrology and Water Resources Symposium of the I.E. Australia and $2^{\text {nd }}$ International Conference on Water Resources and Environmental Research, Brisbane, Australia, 6-8 July, 1999.

Institution of Engineers Australia (1987). Australian Rainfall and Runoff. Institution of Engineers, Australia.

Kuczera, G., (1999). Comprehensive at-site flood frequency analysis using Monte Carlo Bayesian inference. Water Resources Research. 35 (5), 1551-1558.

Kuczera, G., Lambert, M.F., Heneker, T.M., Jennings, S., Frost, A. and Coombes, P. (2003). Joint probability and design storms at the Crossroads. Keynote paper. $28^{\text {th }}$ International Hydrology and Water Resources Symposium, Institution of Engineers Australia, Wollongong, Australia, November 11-13, 2003, 43-61.

Rahman, A., Weinmann, P.E., Hoang, T.M.T. and Laurenson, E.M. (1998). Joint probability approaches to Design Flood Estimation: A Review. Technical Report No. 98/8. Cooperative Research Centre for Catchment Hydrology (CRCCH), Australia, $70 \mathrm{pp.}$

Rahman, A., Weinmann, P.E., Hoang, T.M.T. and Laurenson, E.M. (2002). Monte Carlo simulation of flood frequency curves from rainfall. Journal of Hydrology, 256 (3-4), 196-210.

Russell, S.O., Kenning, B.F.I. and Sunnell, G.J. (1979). Estimating design flows for urban drainage. Journal of the Hydraulics Division, 105 (HY1), 43-52.

Sivapalan, M., Beven, K.J. and Wood, E.F. (1990). On hydrological similarity. 3. A dimensionless flood frequency model using a generalised geomorphologic unit hydrograph and partial area runoff generation. Water Resources Research, 26 (1), 43-58.

US Department of Agriculture, Soil Conservation Service (1986). Section 4: Hydrology. National Engineering Handbook, Washington D.C. 